\title{
Peningkatan Mutu Ikan Asap di Desa Poigar Dua Kecamatan Sinosayang, Kabupaten Minahasa Selatan, Sulawesi Utara
}

\author{
Netty Salindeho $^{1^{*}}$, Inneke F.M. Rumengan ${ }^{2}$ \\ ${ }^{1}$ Program Studi Teknologi Hasil Perikanan, Jurusan Pengolahan Hasil Perikanan, \\ Fakultas Perikanan dan Ilmu Kelautan, Universitas Sam Ratulangi. \\ ${ }^{1}$ Program Studi Ilmu Kelautan, Jurusan Manajemen Sumberdaya Perairan, \\ Fakultas Perikanan dan Ilmu Kelautan, Universitas Sam Ratulangi. \\ Jl. Kampus Unsrat Bahu, Manado 95115, Sulawesi Utara, Indonesia. \\ *Penulis Korespondensi: salindeho.netty@yahoo.com \\ (Diterima 04-11-2019; Direvisi 21-04-2020; Dipublikasi 18-05-2020)
}

\begin{abstract}
ABSTRAK
Ikan asap merupakan produk olahan yang melalui proses penetrasi senyawa volatil pada ikan yang dihasilkan dari pembakaran kayu atau bahan pengasap lainnya, yang dapat menghasilkan produk dengan rasa, warna dan aroma spesifik serta umur simpan yang lama karena adanya aktifitas antibakteri yang dihasilkan dari asap yang ditimbulkan oleh bahan pengasap, serta akibat dari proses pengasapan itu sendiri. Desa Poigar Dua, Kecamatan Sinosayang, Kabupaten Minahasa Selatan, yang secara geografis terletak di pesisir pantai dengan potensi perikanan laut yang potensial untuk dikembangkan. Desa ini dikategorikan sebagai desa dengan mayoritas masyarakat sebagai nelayan yang sekitar $70 \%$. Nelayan di desa ini terdiri dari nelayan penangkap dan pengolah hasil tangkapan. Dari kelompok pengolah hasil tangkapan, ada beberapa nelayan yang membentuk kelompok usaha kecil pengolah ikan asap, dengan jenis ikan olahan tergantung hasil tangkapan yang berlebih, salah satu diantaranya ikan jenis cakalang yang merupakan salah satu produk olahan yang digemari oleh masyarakat sekitar dan pemasaran sebagian tersebar pada pasaran lokal. Tujuan program ini yaitu meningkatkan produksi, pemasaran dan keuangan pada pengusaha kecil pengolah ikan asap di desa target agar terampil dan mandiri secara ekonomi. Target khusus kegiatan ini menghasilkan produk ikan asap yang unggul dari segi rasa, sanitasi dan higiene, daya awet dan penggunaan bahan baku kayu asap yang ramah lingkungan serta memberikan kelangsungan usaha dan manajemen yang tangguh. Adapun metode pelaksanaan yang akan diterapkan pada program ini yaitu 1) Permasalahan kelompok yang disepakati yaitu produksi, pemasaran dan keuangan; 2) Metode pendekatan yang akan ditawarkan untuk mengatasi persoalan kelompok yakni penyuluhan, pelatihan, pendampingan dan evaluasi; 3) Prosedur kerja untuk mendukung ke-3 aspek permasalahan, berturut-turut yaitu survey, penyuluhan, pelatihan, evaluasi, luaran, pelaporan.
\end{abstract}

Kata kunci: Pengasapan, Poigar Dua, Cakalang asap, Pemasaran. Teknologi Pengolahan.

\section{PENDAHULUAN}

Lokasi pengolahan ikan asap ini berada di pinggiran pantai Desa Poigar Dua, Kecamatan Sinonsayang, Kabupaten Minahasa Selatan. Hasil wawancara dengan ketua kelompok untuk banyaknya bahan baku ikan segar yang di olah setiap hari rata-rata $500 \mathrm{~kg} / \mathrm{hari}$. Peralatan dan perlengkapan yang digunakan masih tergolong tradisional. Sumber air yang digunakan untuk mencuci ikan setelah disiangi/dibersihkan isi perut berasal dari air PAM, namun wadah yang digunakan untuk menampung air kurang baik dari segi kebersihan. Tempat pengeluaran isi perut dan insang relatif tidak terlalu baik di lihat dari prinsip sanitasi dan higiene karena hanya dikerjakan di alas kayu yang kecil. Sebaiknya untuk tempat pengeluaran isi perut dan insang pada tempat yang lebih tepat misalnya pada meja kayu atau stainlees steel sehingga sanitasi dan higienenya dapat terjaga karena tempatnya mudah dibersikan dan aman dari bahan pencemar lainnya.

Masyarakat Desa Poigar Dua, Kecamatan Sinosayang terdapat beberapa nelayan yang berprofresi sebagai pengasap ikan. Pengolah ikan asap terletak di pesisir pantai, unit pengolah ikan asap berjumlah 4 tempat lokasi. Bahan baku yang digunakan didapat dari nelayan setempat, dari segi kualitas memiliki kelebihan yakni sebagian besar ikan sebagai bahan baku masih bermutu baik karena ikan baru tertangkap. Ikan asap merupakan ikan olahan tradisional khas Sulawesi Utara. Bahan baku yang digunakan yaitu jenis ikan cakalang. Produksi ikan asap Indonesia sebagian besar berasal dari Sulawesi Utara, sedangkan total produksi ikan asap di Sulawesi Utara 31.908 ton (DKP Sulut, 2010) atau 46,89\% dari total produksi ikan asap Indonesia. komoditi ikan dapat 
dikatakan sebagai exotic indogenous food, namun masih diperhadapkan dengan beberapa permasalahan, antara lain kurang baiknya proses produksi khususnya penggunaan ruang pengasapan yang konstruksi terbuka, pemasaran yang masih terbatas dan modal usaha untuk keberlangsungan proses produksi yang minim.

Ruang pengasapan tidak baik karena kurang efektif sirkulasi asap dan disain bangunan, usaha pengasapan ikan cakalang asap di kelompok masih menggunakan sistim pengasapan suhu pengasapan yang tinggi (pengasapan panas) dengan waktu pengasapan yang relatif singkat sehingga penetrasi komponen asap tidak merata, kadar air produk yang dihasilkan masih tinggi (55-65\%), proses produksi yang belum saniter serta produk tidak dikemas. Produk olahan ini masih bersifat tradisional, karena masih menggunakan cara sederhana dalam teknis pengolahannya seperti penggunaan bahan bakar sabut kelapa.

Aspek Produksi kelompok sebagai berikut :

- Untuk tempat penerimaan bahan baku kurang bersih

- Penyimpanan bahan baku sebelum ikan diolah belum memenuhi prinsip sanitasi dan higienis karena bagian dalam dan luar cool box kotor.

- Prinsip rantai dingin selama proses pengolahan kurang dilakukan.

- Kelebihan dari industri kecil ini yaitu penggunaan bahan baku ikan yang tergolong mutu sangat baik melalui penilaian organoleptik karena setelah ikan ditangkap langsung ditangani/ didaratkan di sekitar lokasi pengoalah ikan asap.

- Bentuk/model cakalang asap yang diproduksi di industri ini masih menggunakan metode konvensional yang telah lama yakni loin belah dua ikan dieratkan pada kayu. Bentuk ini telah lama diterapkan di industri pengolahan ini karena sudah sejak dari orang tua mereka. Metode ini menurut pengolah lebih cepat dan mudah pengerjaannya sehingga efisien dari segi waktu. Walaupun menurut kami dari segi bentuk agak sulit untuk di kemas dan saat produksi memerlukan space lokasi pengasapan yang lebih luas karena produk yang sebenarnya kurang termanfaatkan misalnya bagian kepala diikutkan pada saat pengasapan.

- Hasil olahan masih belum dikemas, dalam proses pemasarannya. Kelompok masih menggunakan kertas koran, cenderung juga tidak layak untuk digunakan sebagai bahan pengemas produk pangan. Kelompok belum memberikan label terhadap hasil olahannya, untuk dapat dipasarkan lebih luas.

\section{METODOLOGI KEGIATAN PKM}

Berdasarkan permasalahan prioritas kelompok pengolah ikan asap yang ada di Desa Poigar Dua, Kecamatan Sinosayang, maka diperlukan penyuluhan, pelatihan dan pendampingan akan aspek produksi, pemasaran dan keuangan pada industri kecil pengasapan ikan. Pengasapan merupakan suatu teknik pengawetan dengan menggunakan asap dari bahan bakar kayu dan bahan bakar lainnya (Winarno, 1980). Pengolahan ikan dengan menggunakan asap untuk konsumsi manusia sebenarnya sudah dikenal sejak lama, tetapi teknik pengolahannya nyaris tidak berubah. Pengasapan merupakan suatu teknik pengawetan dengan menggunakan asap dari bahan bakar kayu dan bahan bakar lainnya (Wibowo, 2000). Menurut Gue (2003) ikan asap yang baik adalah ikan asap yang dibuat dari bahan baku dengan tingkat kesegaran sangat segar, karena menghasilkan rasa, bau, maupun kesan umum yang baik dan daya simpan lama. Cara pengolahannya sangat sederhana, gampang, mudah dikerjakan oleh siapa saja dan biayanya murah, ikan asap yang baik adalah ikan asap yang dibuat dari bahan baku dengan tingkat kesegaran sangat segar, karena menghasilkan rasa, bau, maupun kesan umum yang baik dan daya simpan lama. (Winarno, 2007). Metode pelaksanaan yang akan di terapkan pada program yakni memberikan penyuluhan dan pelatihan bagi kelompok pengasap ikan yang ada di Desa Poigar Dua, Kecamatan Sinosayang, Kabupaten Minahasa Selatan, Sulawesi Utara.

Kegiatan yang dilaksanakan sebagai berikut :

\section{Penyuluhan}

Penyuluhan kepada pelaku industri pengolah ikan cakalang asap di Desa Poigar Dua meliputi:

- Pangan dan Kesehatan Konsumen 
- Kebersihan sarana pengolahan dan lingkungannya mempengaruhi mutu dan keamanan produk ikan asap

- Desain ruang pengasapan ikan yang bersih, saniter, tidak mencemari lingkungan sekitar.

- Perbandingan ruang pengasapan ikan konstruksi terbuka dan tertutup (efektifitas penyerapan asap ke ikan dan optimal penggunaan kayu bakar).

- Bahaya penggunaan bahan kayu bakau (mangrove) sebagai bahan baku pengasapan terhadap kerusakan lingkungan hidup (abrasi pantai).

- Aspek Pemasaran: Permintaan, Penawaran, Analisa Peluang Pasar dan Persaingan.

- Aspek Keuangan: Asumsi dan Parameter Analisis Keuangan.

\section{Pelatihan}

Setelah dilakukan penyuluhan terhadap pelaku industri pengolah ikan asap, kemudian ditindaklanjuti dengan pelatihan pengolahan ikan asap dengan perlakuan sebagai berikut:

Mitra 1. Usaha Baru: Ikan diasap pada ruang pengasapan tertutup (disain pengusul), menggunakan peralatan penunjang cool box, wadah penampung air bersih dan wadah penampung ikan serta menggunakan bahan bakar sabut kelapa.

Mitra 2. Maju Bersama: Ikan diasap pada ruang pengasapan terbuka, menggunakan peralatan yang biasa mereka gunakan, kayu bakar non bakau dengan teknik penyusunan yang biasa dilakukan.

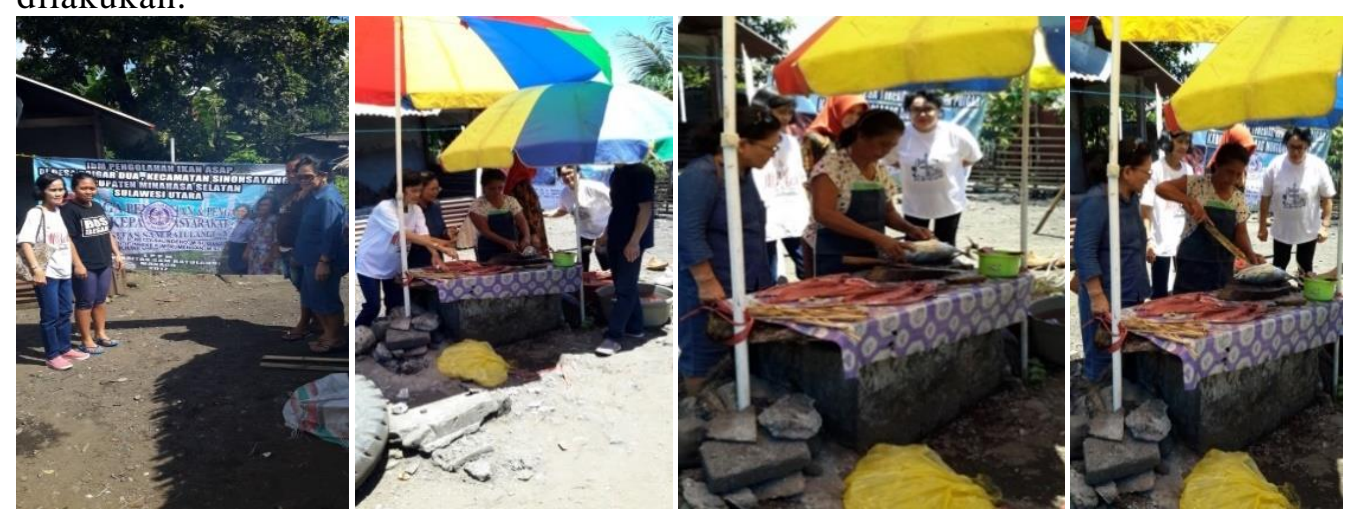

Gambar 1. Proses pengolahan ikan cakalang asap

Tujuan dari pelatihan ini adalah membandingkan penggunan ruang pengasapan tertutup dan terbuka serta melatih teknik pembakaran bahan bakar tanpa menggunakan kayu bakau. Setelah pelatihan produksi selesai dilanjutkan dengan perbaikan ruang pengasapan dan peralatan penunjang pada kelompok. Pelatihan aspek pemasaran: menginformasikan dan mengfasilitasi produk asap yang dihasilkan melalui bazar dan pameran sehingga produk lebih di kenal. Pemasaran juga akan dilakukan melalui departemen store/swalayan di Manado dan sekitarnya. Pelatihan aspek keuangan: melatih perhitungan sederhana biaya investasi (biaya tetap) usaha pengasapan ikan dan biaya operasional: pembelian bahan baku ikan, upah tenaga kerja dan peralatan.

\section{Pendampingan}

Pendampingan dilakukan kepada kelompok meliputi aspek produksi, pemasaran dan keungan dengan jangka waktu setiap minggu.

\section{Evaluasi}

Evaluasi akan dilakukan selama 2 bulan dengan membagikan cek list proses pengolahan ikan asap sesuai prinsip sanitasi dan higiene serta membandingkan kegiatan yang sebelum dan sesudah menerima penyuluhan dan pelatihan. Bahan yang digunakan dalam pelaksanaan PKM ini adalah Ikan Cakalang (Katsuwonus pelamis) dan bahan pengasap sabut kelapa yang digunakan masyarakat Desa Sinosayang untuk membuat ikan cakalang asap.

\section{HASIL DAN PEMBAHASAN}

Kegiatan PKM yang dilaksanakan pada kelompok pengolah ikan asap di Desa Poigar Dua Kecamatan Sinosayang, Kabupaten Minahasa Selatan telah mencapai sasaran dan berhasil guna bagi kedua mitra. Kedua kelompok pengolah mendapatkan manfaat yang maksimal selama 
kegiatan ini, penyuluhan dan pelatihan mengenai sortasi bahan baku ikan cakalang, pengolah ikan cakalang asap menggunakan metode yang tepat, penggunaan bahan pengemas yang saniter dan hygienis serta pengelolaan keuangan yang baik dan pemasaran produk yang benar.

Kegiatan ini diawali dengan melaksanakan survey lapangan ditempat pengolahan ikan asap kedua mitra. Lokasi tempat pengasapan dan lingkungan sekitarnya belum cukup memadai sebagai tempat pengolahan ikan, rumah asap masih sangat sederhana dengan peralatan pengasapan seadanya. Kebersihan lingkungan sekitar tempat pengasapan perlu mendapat perhatian tentang sanitasi dan hygienis bagi produk olahan makanan (ikan). Tempat penampungan bahan baku ikan segar yang terbatas dimana hal ini mempengaruhi kualitas bahan baku untuk ikan asap. Dari percakapan yang dilakuakan selama kegiatan ini kedua kelompok pengolah menyampaikan semua keterbatasan dan kendala yang dihadapi, mereka juga menyampaikan niat yang besar untuk perubahan usaha mereka ke arah yang lebih baik dengan kemauan untuk menerima masukan dari berbagai pihak.

Tahapan pertama kegiatan ini yaitu melakuakan penyuluhan dan pelatihan meng enai sortasi bahan baku ikan yang berkualitas baik. Hal ini penting karena untuk menghasilkan produk akhir yang baik, kelompok pengolah harus memperhatikan kualitas bahan baku yang digunakan. Cara penggunaan tempat penyimpanan bahan baku yaitu cool box jug a dilakukan selama kegiatan ini sehingga ikan yang dibeli dengan kualitas yang baik dapat segera disimpan dalam penyimpanan dingin. Bantuan pengadaan cool box bagi kelompok pengolah sangat bermanfaat, juga diajarkan cara penggunaannya sehingga mereka dapat segera menggunakannya untuk menyimpan bahan baku ikan segar. Selama ini kendala yang mereka hadapi yaitu ketika bahan baku berlimpah dan belum dapat mengolah ikan saat itu juga mereka tidak mempunyai tempat penyipanan dingin agar dapat menjaga kualitas bahan baku untuk di olah keesokan harinya.

Tabel 1. Hasil analisis proksimat ikan cakalang asap menggunakan nanokitosan sebagai pengawet.

\begin{tabular}{lrrrrr}
\hline Perlakuan Pengasapan & \multicolumn{1}{c}{ Kadar Air } & \multicolumn{1}{c}{ Kadar Protein } & \multicolumn{1}{c}{ Kadar Lemak } & \multicolumn{1}{c}{ Kadar Abu } & \multicolumn{1}{c}{ Karbohidrat } \\
\hline Sebelum diasap & $58,50 \pm 0,12$ & $36,06 \pm 0,15$ & $2,23 \pm 0,10$ & $2,10 \pm 0,05$ & $0,70 \pm 0,34$ \\
Sesudah diasap & $61,12 \pm 0,07$ & $31,30 \pm 0,13$ & $2,80 \pm 0,18$ & $2,08 \pm 0,09$ & $0,95 \pm 0,20$ \\
\hline
\end{tabular}

Kegiatan selanjutnya yaitu pelatihan tentang tahapan proses produksi ikan cakalang asap yang menggunakan metode yang tepat yaitu dengan memperhatikan suhu dan waktu pengasapan. Juga bahan bakar yang digunakan, sehingga kualitas ikan asap akan lebih baik. Rangka yang digunakan untuk penyangga ikan selama pengasapan diganti dengan rangka besi yang lebih kuat untuk menampung ikan lebih banyak tiap kali pengasapan. Kebersihan selama pengolahan harus diperhatikan yaitu sejak pencucian ikan menggunakan air bersih sehingga akan menghasilkan ikan asap yang berkualitas dan aman untuk dikonsumsi. Dianjurkan untuk tidak menggunakan bahan pewarna tambahan, apalagi bahan pewarna yang digunakan tersebut berbahaya untuk digunakan sebagai pewarna bahan pangan. Setelah mengikuti pembinaan dan pendampingan dalam hal penyuluhan mengenai pengasapan serta prinsip-prinsip sanitasi dan higienis pengolah ikan cakalang asap mampu menerapkan dan mempraktekan cara-cara pengolahan, dan penyimpanan produk yang di jual agar mutu dan kualitas produk terjamin yang berdampak pada peningkatan produksi dan pemasaran.

\section{KESIMPULAN}

Kagiatan pelaksanaan PKM di Desa Poigar Dua Kecamatan Sinosayang, Kabupaten Minahasa Selatan dapat disimpulkan bahwa: kegiatan penyuluhan dan pelatihan sortasi ikan cakalang, pengesan ikan di dalam cool box, metode pengasapan ikan yang tepat, pengemas yang saniter/hygienis serta pelatihan sanitasi lingkungan telah terjadi peningkatan pemahaman yang signifikan sedangkan penerapan sistem sanitasi dan hygiene di tempat penjualan ikan masih perlu ditingkatkan melalui pelatihan dan penyuluhan yang lebih intensif.

\section{DAFTAR PUSTAKA}

Afrianto, E dan E. Liviawaty,(1989). Pengawetan Dan Pengolahan Ikan. Kanisius. Yogyakarta. 
Fawzya, YN. Murniyati dan Suryaningrum TD. (2011). Persyaratan Pengolahan Produk Perikanan. Balai Besar Penelitian dan Pengembangan Pengolahan Produk dan Bioteknologi Kelautan dan Perikanan. Kementerian Kelautan dan Perikanan.

Gue, H. (2003). Warna Alami Pada Ikan Asap Yang Dibuat Dari Bahan Baku Dengan Tingkat Kesegaran Dan Lama Pengasapan Yang Berbeda Serta Kesukaan Terhadap Ikan Asap Yang Diberi Zat Pewarna. Skripsi. Fakultas Perikanan Dan Ilmu Kelautan. Unsrat. Manado.

Salindeho N. Purnomo, H., Yunianta, and Kekenusa J. (2014). Physicochemical Characteristics and Fatty Acid Profile of Smoked Skipjack Tuna (Katsuwonus pelamis) Using Coconut Fiber, Nutmeg Shell and Their Combination as Smoke Sources. International Journal of Chem Tech Research. CODEN (USA): IJCRGG 6 (7): 3841-3846. ISSN0974-4290.

Salindeho N and Hens Onibala. (2017). Physico-Chem ical Characteristics, Fatty Acid Profile and Polycyclic Aromatic Hydrocarbon of Skipjack Tuna (Katsuwonus pelamis) Smoked in Smoking Material of Nutmeg Shells for Different Duration in Bitung Municipality, North Sulawesi Province. International Journal of Chem Tech Research. CODEN(USA) ISSN:0974-4290 IJCRGG. Vol.10, No.4, pp 506-512- 2017.

Salindeho N. and Mamuaja Christine. (2015). Physico-chemical characteristics and fatty acid profiles of smoked skipjack tuna (Katsuwonus pelamis) from several producers in Bitung Municipality, North Sulawesi, Indonesia. International Journal of Chem Tech Research. CODEN(USA) IJCRGG 8 (1): 356-361. ISSN :0974-4290.

Salindeho, N. (2017). Karakteristik Fisiko Kimia, Profil Asam Lemak Ikan Cakalang Asap Menggunakan Bahan Pengasap Sabut Kelapa Dan Cangkang Pala. JPHPI, 20(2), 392-400.

Wibowo, S. (2000). Industri Pengasapan Ikan. Penerbit PT. Penebar Swadaya. Jakarta.

Winarno, F.G. (1980). Kimia Pangan. Pus BangTepa Food Technologi Development Center. Institut Pertanian Bogor.

Winarno, F.G. (2004). Hazard Analysis Critical Control Point (HACCP). M-Brio Press.

Winarno, F.G. (2007). Teknobiologi Pangan. M Brio Press. Bogor. 